\title{
IR thermography applies to the detection of solar panel
}

\author{
Termografía de infrarrojos aplicada al seguimiento y detección de anomalías en paneles fotovoltaicos
}

Francisco José Suárez-Domínguez (Main and Contact Author) Universidad de Oviedo. Dpto. de Construcción e Ingeniería de Fabricación. Escuela Politécnica de Mieres, España.

C/ Gonzalo Gutiérrez Quirós s/n - 33600 Mieres

+34985458183, +34985182655

fransd@uniovi.es

\section{María Belén Prendes-Gero}

Universidad de Oviedo. Dpto. de Construcción e Ingeniería de Fabricación. Escuela Politécnica de Mieres, España.

mbprendes@uniovi.es

\begin{abstract}
Solar panels with photovoltaic cells that generate solar power for inclusion in the electricity grid have been installed in the south-facing wall of the Science and Technology Building in the University of Oviedo (Spain) in order to generate clean energy. We describe the application of infrared thermography to the monitoring and detection of defects in the solar panels, based on measurements made in situ between January and May 2011. The results show temperature differences in the panels attributable to panel defects, poor panel functioning or defects in panel assembly and arrangement.
\end{abstract}

Keywords: infrared thermography; photovoltaic panels; defects detection; defects monitoring; preventive maintenance

\section{Introduction}

The estimation of the service life of the elements of a building, and the detection of possible anomalies on them are essential parts of drawing up a realistic and economically viable maintenance program (Ortega et al., 2015), (Arco et al., 2013).

In this work, we describe the use of infrared thermography (IRT) to detect anomalies in photovoltaic cell panels (ENERGY $10,2000)$ used to generate electrical energy. The solar panel installation is located on the south-facing wall of the Science and Technology Building in the University of Oviedo (Spain).

IRT is an instrumental technique that converts a given spatial distribution of thermal radiation (an infrared band signal from the electromagnetic spectrum invisible to humans) into an image. This image, which represents the surface distribution of temperatures in the observed object, can then be measured and thermally analyzed.

IRT has the following advantages (Krapez \& Cielo, 1991):

- It is a non-destructive technique that measures surface temperature and emissivity with no direct contact with the installation.

- As a diagnostic or preventive maintenance technique, it permits in situ analysis and control of processes and materials.

- The fact that it provides real-time information that can be stored digitally implies great flexibility in the study and temporal monitoring of data.

\section{Ángel Martín-Rodríguez}

Universidad de Oviedo. Dpto. de Construcción e Ingeniería de Fabricación. Escuela Politécnica de Mieres, España.

martinangel@uniovi.es

\section{Alberto Higuera-Garrido}

Universidad de Oviedo. Dpto. de Construcción e Ingeniería de Fabricación. Escuela Politécnica de Mieres, España.

aehernandez@uniovi.es

Manuscript Code: 206

Date of Reception/Acceptance: 01-03-2014 / 01-12-2015.

Resumen

En aplicación del empleo de energías limpias se ha dispuesto en la fachada sur del Edificio Científico Tecnológico de la Universidad de Oviedo (España) una instalación de paneles fotovoltaicos, para la obtención de energía eléctrica y su posterior entrega a la red. El presente artículo muestra la aplicación de la termografía infrarroja en el seguimiento y detección de anomalías o defectos en dichos paneles fotovoltaicos, a partir de mediciones in situ, realizadas entre los meses de enero y mayo de 2011. Los resultados obtenidos muestran diferencias de temperatura en los paneles, que pueden ser atribuidas a defectos en las placas, mal funcionamiento de las mismas o defectos en el montaje y disposición de los mismos.

Palabras Claves: termografía de infrarrojos; paneles fotovoltaicos; detección de anomalías; seguimiento de anomalías; mantenimiento preventivo.

\section{Physical Basis Of Thermography}

All materials have the ability to absorb infrared radiation increasing their temperature. Furthermore, any material with a temperature above absolute zero emits infrared energy (Maldague, 2001). This radiant energy is directly proportional to the fourth power of the object surface temperature. StefanBoltzmann Law (Eq. 1).

Where Rt is the radiant energy of a body, $\varepsilon$ is the emissivity $(0 \leq \varepsilon \leq 1), \sigma$ is the Stefan-Boltzmann constant $\left(5,67 \cdot 10^{\wedge}(-8)\right.$ $\left.W m^{\wedge}(-2) K^{\wedge}(-4)\right)$ and $T$ is the absolute temperature of the body. Emissivity is defined as the quotient between the radiation emitted by a body and the radiation emitted by a black body (a body that absorbs all the incident radiation) to the same temperature. This coefficient allows to classify the bodies like black ones $(\varepsilon=1)$ and grey ones $(\varepsilon<1)$.

Although emissivity is considered a characteristic constant of each material, in fact it is function of wavelength, temperature and emission angle. In the same way, the emitted radiation is not constant for all the wavelengths. Its spectral distribution fulfils the law of Plank (Eq. 2).

$R_{-} t=\varepsilon \cdot \sigma \cdot T^{\wedge} 4\left(W m^{\wedge}(-2)\right)$

$\mathrm{dR}(\lambda, \mathrm{T}) / \mathrm{d} \lambda=2 \pi \mathrm{c \varepsilon}(\lambda, \mathrm{T}) /\left(\mathrm{e}^{\wedge}(\mathrm{hc} / \lambda \mathrm{kT})-1\right)$

From Eq. 2 it is possible to say that with a temperature around $297 \mathrm{OK}$, the maximum emitted radiation takes place at wavelengths located in the infrared spectrum band. In particular, it takes place in wavebands between $700 \mathrm{~nm}$ and $20000 \mathrm{~nm}$ 
However, the radiation that reaches the receiver is not only the emitted one but also the parasitic radiation composed of the radiation emitted by other bodies and by the light sources close to the receiver. This parasitic radiation can produce an increase of the temperatures.

Measurement also depends on the angle of incidence of the observation although its influence is null with low angles.

The atmosphere in which thermal radiation is transmitted also plays an important role by absorbing or scattering some of the radiation. However, there are wavelength intervals where the atmosphere is almost transparent. These ones are called transmission windows, and are located between 8 and $13 \mu \mathrm{m}$ at room temperature.

\section{Description of the experiment}

\section{Location and characteristics of the installation}

The studied photovoltaic panels were installed in one of the outer glass south-facing walls of the Science and Technology Building in the University of Oviedo (Spain) in September 2008 (Fig. 1). Its purpose is generating electrical energy for its delivery to the network.

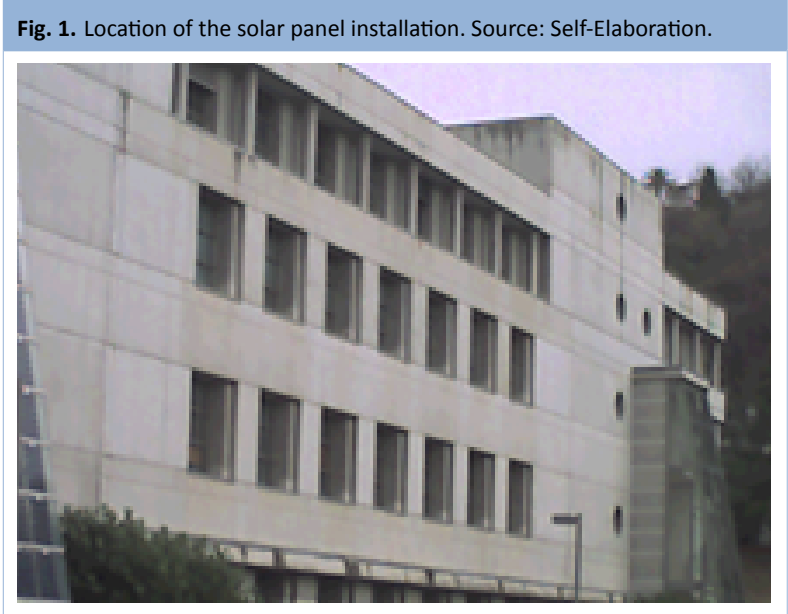

Table 1. Installation losses due to orientation and shadow.

Source: Self-Elaboration from public information of SILIKEN

\begin{tabular}{lccl}
\hline & $\begin{array}{c}\text { Orientation } \\
\text { and tilt }\end{array}$ & Shadow & Total \\
\hline General & $10 \%$ & $10 \%$ & $15 \%$ \\
\hline Superimposition & $20 \%$ & $15 \%$ & $30 \%$ \\
\hline Architectural integration & $40 \%$ & $20 \%$ & $50 \%$ \\
\hline
\end{tabular}

The photovoltaic system consists of a Photovoltaic Solar Generator formed by 44 polycrystalline photovoltaic modules of two different types: 22 modules are GG25M5 of $61 \mathrm{Wp}$, and 22 ones are GG36M5 of $92 \mathrm{Wp}$. All of them are SILIKEN modules. The modules are distributed in series forming a unique group. This group is coupled to an inverter who operates in parallel with the mains. The maximum losses due to orientation and tilt, by shadow and the total losses do not exceeded the values reflected in Table 1.

The SILIKEN modules, with $13,9 \%$ conversion efficiency, provide variations in nominal characteristics for the following temperature coefficients: $127,2 \mathrm{mV} / \mathrm{o} \mathrm{C}$ for open-circuit voltage, $2,2 \mathrm{~mA} /{ }^{\circ} \mathrm{C}$ for short-circuit current, $0,4 \% / ㅇ ㅡ$ for power. Real maximum power and short-circuit current fall in the range of $\pm 5 \%$ of the nominal values and maximum voltage is $750 \mathrm{~V}$. The two different models used are photovoltaic square polycrystalline silicon cells of high efficiency, with a size of $156 \mathrm{~mm} \times 156 \mathrm{~mm} \pm 0,5 \mathrm{~mm}$.

The cells thickness ranges between $300 \mu \mathrm{m}$ and $270 \mu \mathrm{m}$. The $2 \mathrm{~mm}$ thick silver buses have been treated with anti-reflective silicon nitride to produce energy even at very low levels of solar radiation. This fact ensures continuous production from the dawn to the dusk, by mean of the capture of all the useful power supplied by the sun.

In terms of functioning, the energy received from the sun is converted by the photovoltaic modules into electrical energy (King, 1997), (Davis, et al., 2001). This energy is leaded an inverter that transform the direct current into alternating current. This transformation let the direct connection to the mains distribution company because it is perfectly synchronous and fulfils with all standards regarding maximum allowable tolerances and distortion (Fig. 2).

The maximum discharge rate of the photovoltaic system is 4,77 $\mathrm{kW}$. The supplied signal has a frequency of $50 \mathrm{~Hz}$, a voltage of $250 \mathrm{~V}$ and a power factor ( $\cos \phi)$ among 0,8 to 1 . These values satisfy the tolerance and quality requirements of applicable legislation. With these conditions and since it is an installation with a nominal power smaller than $20 \mathrm{~kW}$, the feed-in tariff is $0,34 €$ per kW/h (Spanish Royal Decree 1578/2008).

\section{Data capture}

The thermography data (Thomas, 1999) were obtained using a Testo-800-3 thermal camera whose basic technical characteristics are shown in Table 2, and that confirm the data obtained for (Chrzanowski, 2001). The atmospheric conditions prevailing at the time of data acquisition were recorded by a mobile ECRON EH2325 station.

Fig. 2. One-line wiring diagram. Source: Self-Elaboration.

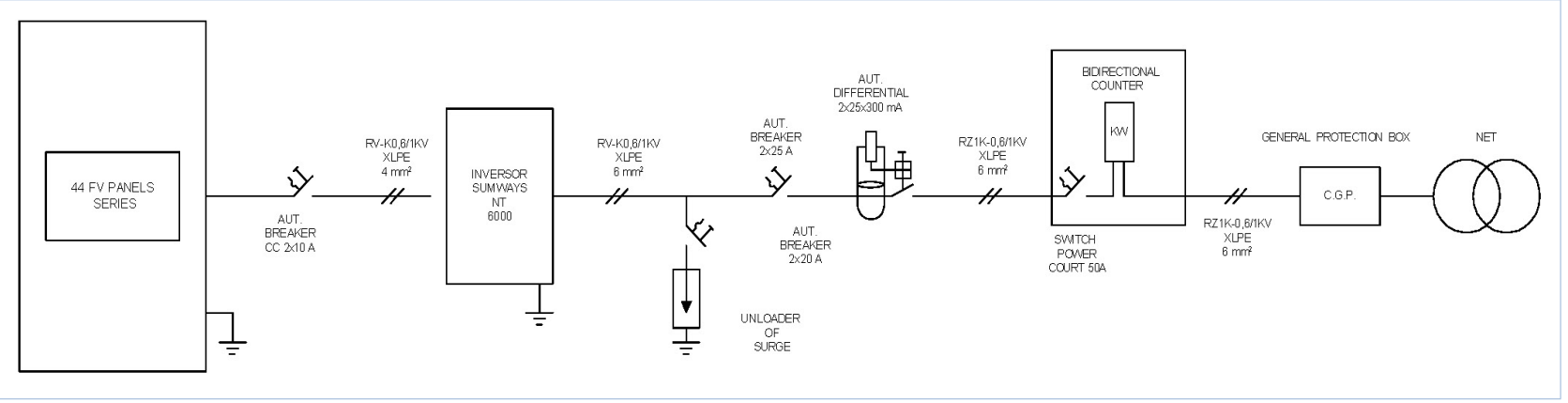


Emissivity was determined by comparison of temperatures. The temperature of the surface to analyze was moderate, first with a thermometer of contact, and later with the thermal camera with the emissivity fit to $\varepsilon=1$. These values are compared and emissivity adjusts gradually until the temperature detected by camera corresponds to that one of the contact (ASTM, 2010). The emissivity value for the panels were set to $\varepsilon=0,8$.

In situ measurements were made at the same time of day between January and May 2013. The meteorological and environmental conditions: temperature, humidity and wind, are collected in Table 3.

\begin{tabular}{|c|c|}
\hline \multicolumn{2}{|l|}{ INFRARED IMAGES } \\
\hline Characteristic & Values \\
\hline $\begin{array}{l}\text { Visual field/min. focus } \\
\text { distance }\end{array}$ & $\begin{array}{l}\text { Standard objective lens: } 32^{\circ} \times 24 \% / 0,1 \mathrm{~m}(0,33 \mathrm{ft}) \\
\text { Telephoto lens: } 12^{\circ} \times 9 \circ / 0,6 \mathrm{~m}(1,97 \mathrm{ft})\end{array}$ \\
\hline $\begin{array}{l}\text { Thermal sensitivity } \\
\text { (NETD) }\end{array}$ & $<0,1 \mathrm{k}$ to $30^{\circ} \mathrm{C}\left(<0,18^{\circ} \mathrm{F}\right.$ to $\left.86^{\circ} \mathrm{F}\right)$ \\
\hline \multicolumn{2}{|l|}{ MEASUREMENT } \\
\hline Characteristic & Values \\
\hline $\begin{array}{l}\text { Temperature range } \\
\text { (commutable) }\end{array}$ & $\begin{array}{l}-20^{\circ} \text { to } 100^{\circ} \mathrm{C} / 0^{\circ} \text { to } 350^{\circ} \mathrm{C} \\
\left.\text { (-4을 to } 212^{\circ} \mathrm{F} / 32^{\circ} \text { to } 662^{\circ} \mathrm{F}\right)\end{array}$ \\
\hline Accuracy & $\pm 2^{\circ} \mathrm{C}\left( \pm 3^{\circ} \mathrm{F}\right)$ or $\pm 2^{\circ} \mathrm{C}$ of the greatest value \\
\hline Emissivity adjustment & $\begin{array}{l}8 \text { materials }+1 \text { personalized } \\
\text { (freely defined between } 0,01 \text { and } 1,00 \text { ) }\end{array}$ \\
\hline \multicolumn{2}{|c|}{ ENVIRONMENT CONDITIONS } \\
\hline Characteristic & Values \\
\hline $\begin{array}{l}\text { Operational } \\
\text { temperature }\end{array}$ & $-15^{\circ}$ to $40^{\circ} \mathrm{C}$ ( 5 을 $\left.113^{\circ} \mathrm{F}\right)$ \\
\hline Environment humidity & $\begin{array}{l}20 \% \text { to } 80 \% \text { relative humidity with no } \\
\text { condensation }\end{array}$ \\
\hline
\end{tabular}

\begin{tabular}{ccccl}
\multicolumn{6}{c}{ Table 3. Atmospheric conditions. Source: Self-Elaboration. } \\
\hline Date & Time & \multicolumn{1}{c}{$\begin{array}{c}\text { Temperature } \\
\text { oC }\end{array}$} & $\begin{array}{c}\text { Humidity } \\
\%\end{array}$ & Wind \\
\hline $11-01-2013$ & $12: 00$ & 6,5 & 75 & Null \\
\hline 09-02-2013 & $12: 00$ & 11,0 & 70 & Null \\
\hline 09-03-2013 & $12: 00$ & 15,0 & 75 & Null \\
\hline 06-04-2013 & $12: 00$ & 16,0 & 80 & Null \\
\hline 06-05-2013 & $12: 00$ & 17,0 & 88 & Null \\
\hline
\end{tabular}

\section{Data management and processing}

Once the data were collected they were computerized and processed (Krapez \& Cielo, 1991) using the Testo IRSoft ${ }^{\circledR}$ software. This tool allows to plot, from the thermal image, different graphs of profiles and histograms of temperatures (International Organization for Standardization, 1983), (Kaplan, 2001) as much of the complete installation as of zones that show stranger values. These zones will be named critic zones.
Results: analysis and evaluation

The processed thermography data were analyzed and evaluated in terms of three aspects: general installation, groups of panels, localized areas or critic zones. In all the cases, examples of the results are given below and in them are included the thermal and real image and the temperature profile.

\section{General installation}

The thermography image (Fig. 3a) shows a very uniform temperature distribution with a $95 \%$ of the surface with temperatures between $18,5^{\circ}$ and $21^{\circ} \mathrm{C}$, and some isolated points with temperatures above $22,5 \circ \mathrm{C}$. The same results are obtained from the vertical temperature profile (Fig. 3c). In addition, in this case the image shows a very light reduction of the temperature from the highest zone of the building to the lowest one. This behavior is caused by the lean of the building.

However, from this previous analysis it is possible to divide the area of study in three anomalous different zones:

- Zones with lower temperatures, between 170 and 18ㅇ C. These ones come from the metal supports.

- Zones with higher temperatures. These ones come from the panels near to the metal supports. In this case the metal sections increase the temperature due to the solar radiation reflected (Lyberg, Mattsson, \& Sundberg, 1990), (Seeber, 1984).

- $\quad$ Critic zones. These points display very high temperatures $\left(23^{\circ} \mathrm{C}\right)$ with respect to the average one. These values can be the result of damages in some cells or damage inside the circuit of transport, and they must be analyzed.

\section{Groups of panels}

In the same way that the analysis previous, the study of the different panels shows that a great percentage of the surface has temperatures with values near to the average one. As it was previously mentioned, the lean of the building produce changes in the temperature so the average value of the panel depends on its situation. However, in all the panels it was found that the average value is bigger that the gotten in the general installation. This increase is because of the exclusion from the analysis, of the metal supports and the gaps between panels.

But although the metal supports are outside the analyzed area, they cause that the nearest cells display higher temperatures (Fig. 4a). In the panels there are also areas with lower temperatures than the average one. These areas are the separations between panels (Fig. 4c). 


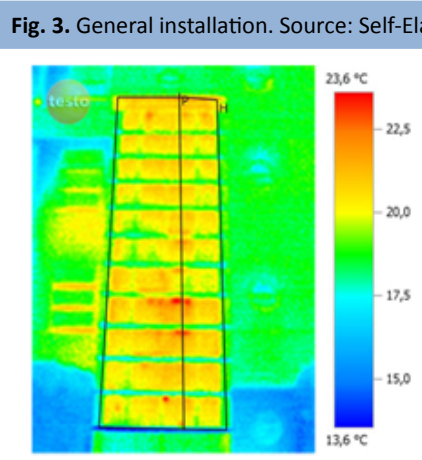

a. Thermography image

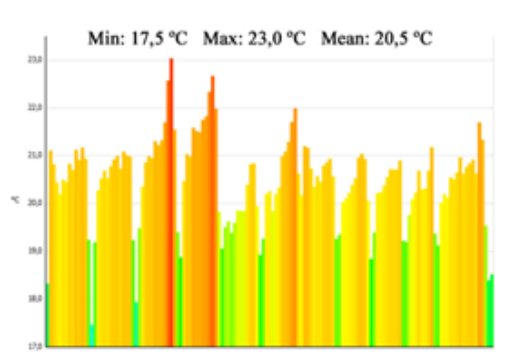

c. Temperature profile

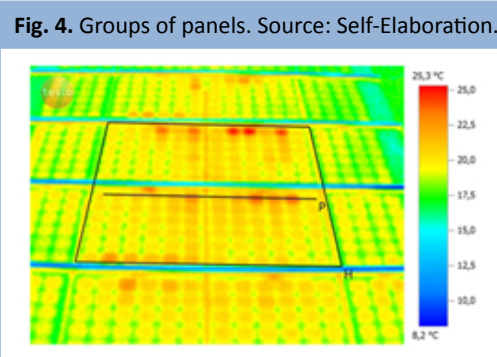

a. Thermography image Min: $19,6^{\circ} \mathrm{C}$ Max: $24,1^{\circ} \mathrm{C}$ Mean: $21,2^{\circ} \mathrm{C}$

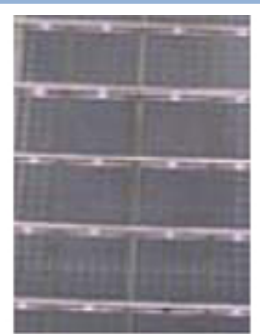

b. Real image

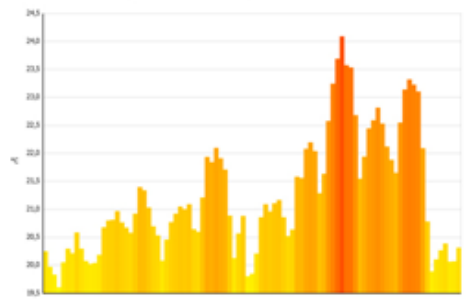

c. Temperature profile

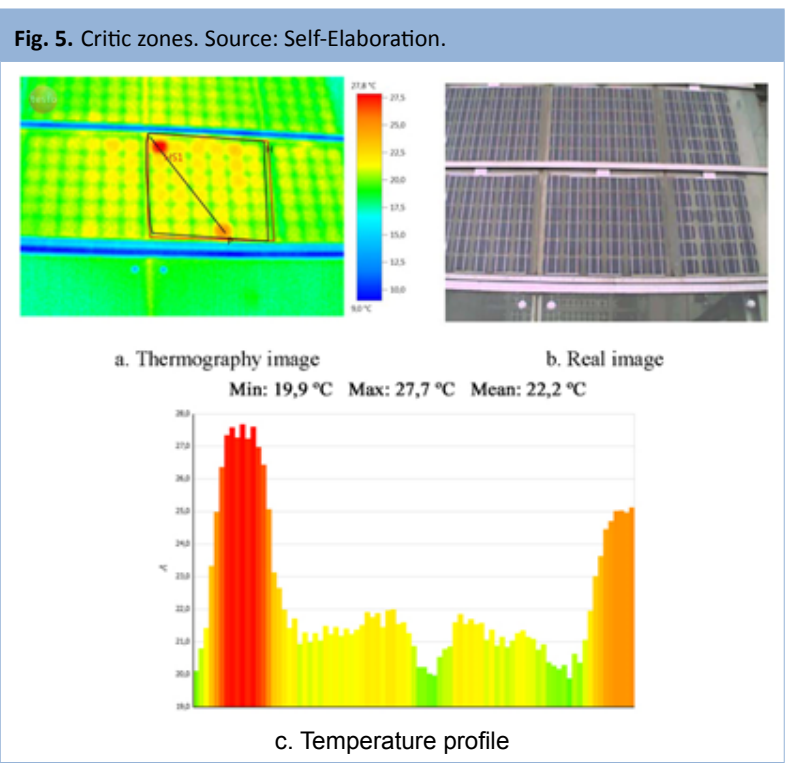

Critic zones

The study of the general installation has showed one critic zone in the lower panel of the building (Fig. 3a). The analysis of this zone has displayed two hot spots (Fig. 5a) with temperatures around 26 and $28 \stackrel{\circ}{\circ}$ against an average temperature of 21 oC (Fig. 5c). Their visual inspection (Fig. 6) has revealed that these high temperatures were due to deterioration in the cellto-junction box transmission circuit that generated a positive temperature gradient.

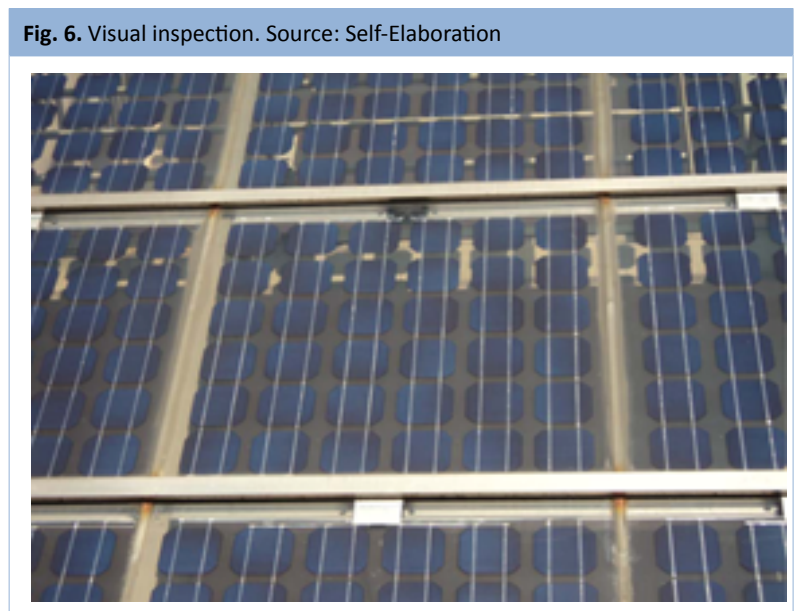

\section{General methodology for the procedure}

After the study carried out, it was established the criteria to be followed for a correct implementation of the steps of the procedure. These criteria can be applied in buildings where integrated panels in roofs or facades can be assessed. The objective is to ensure repeatability when it comes to gathering data (obtaining thermograms).These criteria are:

Location and signage. This phase entails the selection and identification of the points for taking the samples, based on criteria such as accessibility, repeatability and the operational requirements of the operation itself. Once they have been selected and identified, the points are marked using markers that can be identified on site, their geodesic coordinates are recorded, and the frequency with which data will be collected is determined. This phase can be summarized as: choosing and identifying the points for taking samples, applying signage to the points for taking samples, preparing the file for location and signage

Data collection. Once the points have been selected and identified, the data are collected on site, or rather the thermograms are taken and the physical and environmental parameters are determined at that point. The majority of the thermographic cameras on the market store the information on digital memory, which facilitates its subsequent processing and management. The steps of this phase are: frequency of data collection, determining the physical and environmental parameters (for example ambient temperature, reflected temperature or relative humidity), taking the thermograms, preparing the file for data collection

Data management and analysis. The information gathered on site is transferred to a database for management and analysis. The existence and maintenance of this database makes it possible to determine not just the actual state of the areas being studied but also their behavior and evolution over time. The protocol for the procedure for managing and handling data essentially consists of: identifying the areas with 
possible anomalies, analyzing the current state, comparing the

current state with previous states, preparing the analysis and management file

Based on the previous analysis it is possible to identify and evaluate the areas with anomalies. Three levels are established with different protocols for action (Fig. 7).

- No anomalies: continue gathering and monitoring data with the established frequency

- $\quad$ Possible anomalies: increase the frequency for gathering and monitoring data.

- Anomalies: proceeded to carry out the required operations to eliminate the failure

\section{Conclusions}

The infrared thermography is a reliable, economic and easily applied technique for the monitoring and preventive maintenance of photovoltaic installations. The profile of temperatures let to recognize hot spots that reflect the damages in some cells or damages inside the circuit of transport without having access to the installation. It is possible to establish a methodology with the end of ensuring the repeatability of the procedure. It can be concluded that the solar panels, after almost three years of operation, are in a satisfactory condition, except for some minor flaws that can easily be corrected.
American Society for Testing and Materials. (2010). Standard Test Methods for Measuring and Compensating for Emissivity Using Infrared Imaging Radiometers. West Conshohocken, Pennsylvania: American Society for Testing and Materials. http://doi.org/10.1520/E1933-99AR10

Arco, J., Sánchez, J., Saucedo, R., Gil, F., Salmerón, J. M., \& Molina, J. L. (2013). Gestión y rehabilitación energética de edificios existentes: procedimiento experimental de diagnosis y caracterización energética. Revista de La Construcción, 12(3), 9-16.

Chrzanowski, K. (2001). Evaluation of thermal cameras in quality systems according to ISO 9000 or EN 45000 standards. In A. E. Rozlosnik \& R. B. Dinwiddie (Eds.), Proc. SPIE 4360, Thermosense XXIII (p. 15). Orlando, Florida: Society of Photo Optical. http://doi.org/10.1117/12.421015

Davis, M. W., Fanney, A. H., \& Dougherty, B. P. (2001). Prediction of Building Integrated Photovoltaic Cell Temperatures. Journal of Solar Energy Engineering, 123(3), 200. http://doi. org/10.1115/1.1385825

ENERGY 10.(200). Energy 10. A Tool for Designing Low Energy Buildings. Washington, D.C: Sustainable Buildings Energy Council.

International Organization for Standardization. (1983). Thermal insulation - Qualitative detection of thermal irregularities in building envelopes - Infrared method. Berlín: International Organization for Standardization.

Kaplan, H. (2001). ASNT Level III Study Guide: Infrared and Thermal Testing Method (IR) (3rd ed.). Columbus, Ohio: The American Society For Nondestructive Testing.

King, D. L. (1997). Photovoltaic Module and Array Performance Characterization Methods for All System Operating Conditions. Review Literature And Arts Of The Americas, 1-22. http://doi.org/10.1063/1.52852

Krapez, J. C., \& Cielo, P. (1991). Thermographic nondestructive evaluation: Data inversion procedures. Research in Nondestructive Evaluation, 3(2), 81-100. http://doi. org/10.1007/BF01577647

Lyberg, M. D., Mattsson, M., \& Sundberg, J. (1990). Detection of moisture damage in buildings using thermography. In S. A. Semanovich (Ed.), Proc. SPIE 1313, Thermosense XII: An International Conference on Thermal Sensing and Imaging Diagnostic Applications (p. 6). Orlando, Florida: Society of Photo Optical. http://doi.org/10.1117/12.21918

Maldague, X. P. (2001). Theory and Practice of Infrared Technology for Nondestructive Testing. (John Wiley and Sons Ltd, Ed.) (1st ed.). New York: Wiley-Interscience.

Ortega Madrigal, L., Serrano Lanzarote, B., \& Fran Bretones, J. M. (2015). Proposed method of estimating the service life of building envelopes. Revista de La Construcción, 14(1), 60-68.

Seeber, S. A. (1984). Use of Infrared Thermography for the Identification of Design and Construction Faults in Buildings. In Gordon J. Burrer (Ed.), Proc. SPIE 0446, Thermosense VI: Thermal Infrared Sensing for Diagnostics and Control (p. 8). Oak Brook, Illinois: Society of Photo Optical. http://doi.org/10.1117/12.939143

Thomas, A. R. (1999). The Thermography Monitoring Handbook (1st ed.). Oxford, United Kingdown: Coxmoor Publishing Company. 


\section{LOCATION AND SIGNAGE}

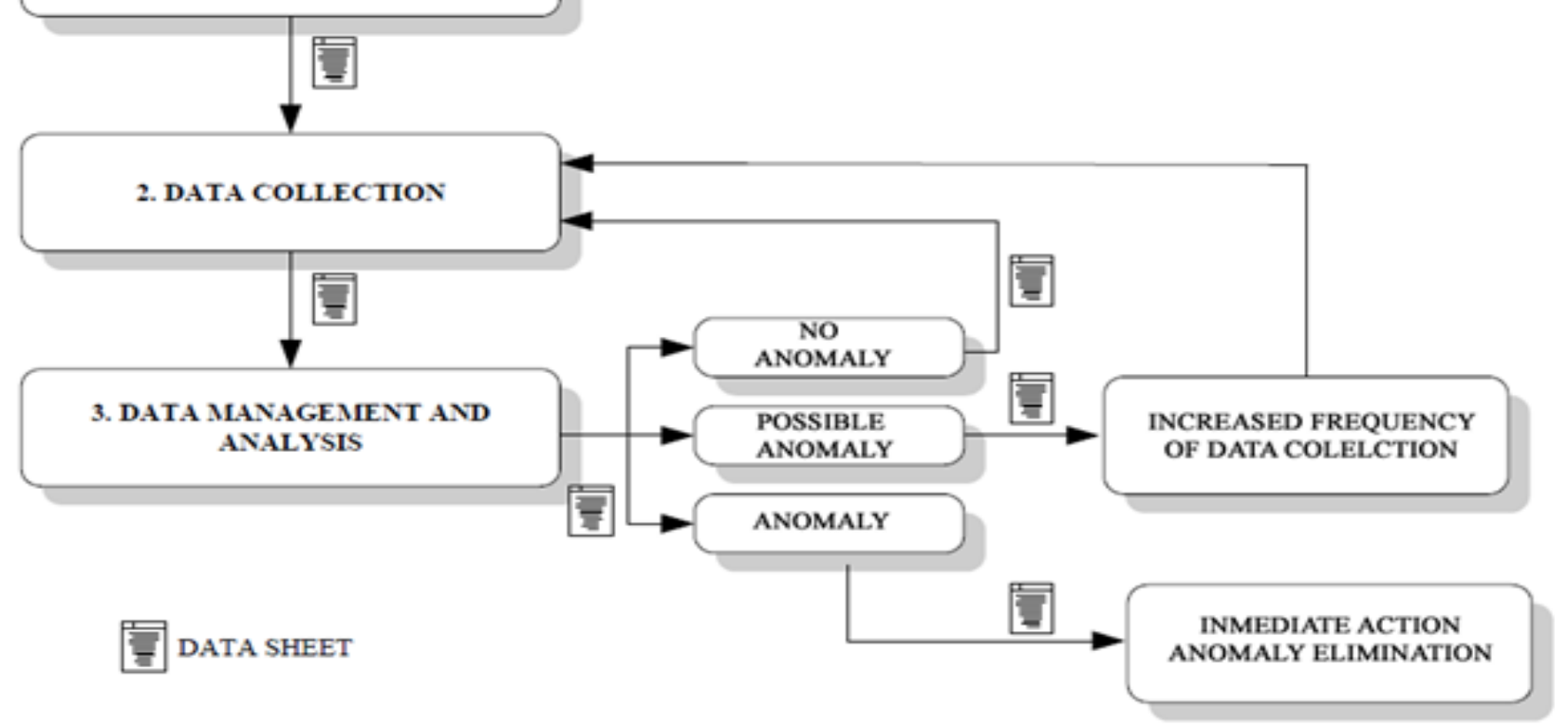

